\title{
PATRYSTYCZNA INTERPRETACJA RDZ 2, 7: „PAN BÓG ULEPIL CZLOWIEKA Z PROCHU ZIEMI I TCHNĄŁ W JEGO NOZDRZA TCHNIENIE ŻYCIA"
}

Sposób pojawienia się człowieka na ziemi od zawsze fascynował ludzkość. Próbowano wyjaśnić ten fenomen przy pomocy różnych teorii, bardziej lub mniej naukowych, popartych przekonywującymi dowodami lub też ich brakiem. Chrześcijanie problem ten usiłowali często rozwiązać w oparciu o Księgę Rodzaju. Istnieją w niej dwa opisy stworzenia człowieka. W pierwszym czytamy następujące słowa:

„A wreszcie rzekł Bóg: «Uczyńmy człowieka na Nasz obraz, podobnego Nam. Niech panuje nad rybami morskimi, nad ptactwem powietrznym, nad bydłem, nad ziemią i nad wszystkimi zwierzętami pełzającymi po ziemi!» Stworzył więc Bóg człowieka na swój obraz, na obraz Boży go stworzył: stworzył mężczyznę i niewiastę" (Rdz 1, 26-27)'.

Drugi natomiast opis, bardziej zwięzły, brzmi następująco:

„wtedy to Pan Bóg ulepił człowieka z prochu ziemi i tchnął w jego nozdrza tchnienie życia, wskutek czego stał się człowiek istotą żywą" (Rdz 2, 7)2.

Zarówno jeden jak i drugi fragment stał się przedmiotem badań pisarzy wczesnochrześcijańskich. W komentarzach i homiliach próbowano odczytać nie tylko znaczenie tych opisów, ale także sposób stworzenia człowieka i jego

${ }^{*}$ Ks. dr hab. Bogdan Czyżewski, prof. UAM - profesor nadzwyczajny w Zakładzie Teologii Patrystycznej i Historii Kościoła na Wydziale Teologicznym Uniwersytetu im. Adama Mickiewicza w Poznaniu; e-mail: czybo@amu.edu.pl.

${ }^{1} \mathrm{Na}$ temat patrystycznej analizy pierwszego opisu stworzenia człowieka zob. B. Czyżewski, „Uczyńmy człowieka na Nasz obraz, podobnego Nam” (Rdz 1, 26) w interpretacji Ojców Kościoła, SG 25 (2011) 113-126.

${ }^{2}$ Warto zwrócić uwagę na pewną różnicę istniejącą w tych dwóch opowiadaniach. Według pierwszego człowiek został stworzony jako ostatni ze wszystkich stworzeń, w drugim natomiast jako pierwszy. Niezależnie od tego przesłanie autora natchnionego jest jedno, mianowicie, by ukazać z jednej strony człowieka jako szczytowe, końcowe i najpiękniejsze stworzenie (pierwszy opis), z drugiej zaś jako tego, który jest najważniejszy, ponieważ następne stworzenia uczynione zostały dla niego (drugi opis). Można zatem stwierdzić, że w jednym i drugim opisie chodziło o to samo: pokazanie wielkiej godności człowieka, por. B. Costacurta, Obietnica życia w Księdze Rodzaju, thum. D. Piekarz, Kraków 2004, 27. 
pojawienie się na ziemi. Ciekawy jest bez wątpienia werset $\mathrm{z}$ drugiego opisu, niezwykle syntetyczny, a jednocześnie przedstawiający Stwórcę jako Mistrza kształtującego w swoich dłoniach ludzką postać, nadając jej konkretne rysy i zewnętrzne cechy. Na tym jednak, według biblijnej koncepcji, nie kończy się stworzenie człowieka. Stwórca daje mu coś więcej - tchnienie życia, które powoduje, że może się poruszać, myśleć, odczuwać i dzięki temu nazwany został „istotą żywą”. Ten niezwykle piękny werset Księgi Rodzaju $(2,7)$ nie został wyjaśniony osobno przez pisarzy okresu patrystycznego, ale stanowi część większych bądź też mniejszych objętościowo komentarzy i homilii. Nie jesteśmy oczywiście w stanie przedstawić wszystkich utworów interpretujących Rdz 2, 7, dlatego ograniczymy się do kilku najciekawszych wypowiedzi pisarzy wczesnochrześcijańskich na temat drugiego opisu stworzenia człowieka.

1. Materia użyta do stworzenia człowieka. Ojcowie Kościoła interpretując fragment Księgi Rodzaju mówiący o stworzeniu człowieka zastanawiali się nad rodzajem materii użytej w tym celu przez Boga. We współczesnych thumaczeniach Rdz 2, 7, jak chociażby w Biblii Tysiąclecia, mowa jest o prochu ziemi, z którego został uczyniony człowiek. Septuaginta zaś, którą często posługiwali się pisarze wczesnochrześcijańscy, wspomina, że materią $\mathrm{w}$ dziele ukształtowania człowieka był muł ziemi ${ }^{3}$. Dlatego też autorzy czasów patrystycznych komentujący wspomniany werset próbowali wyjaśnić, czym on był i z jakiego powodu Pan Bóg posłużył się takim a nie innym materiałem w dziele stworzenia człowieka. Nie wolno zapominać, że wypowiedzi Ojców związane z tym właśnie wersetem miały niekiedy charakter polemiczny, ponieważ próbowali oni przeciwstawić się fałszywym poglądom traktującym materię jako zło i więzienie dla duszy człowieka.

Przykładem wspomnianej wyżej polemiki jest bez wątpienia św. Augustyn, który w swoich trzech komentarzach do Księgi Rodzaju ${ }^{4}$ występuje przeciwko manichejczykom. Biskup Hippony komentując zdanie Rdz 2, 7 stawia najpierw pytanie: ,,jaki to był muł (limus), albo też jaka materia została określona nazwą mułu"s. Zanim udzieli na nie odpowiedzi, przywołuje pytania przeciwników na ten sam temat, ale postawione w całkowicie innej, można by powiedzieć, przewrotnej formie:

\footnotetext{
${ }^{3}$ Por. Rdz 2, 7, LXX: „Bóg ukształtował człowieka z mułu ziemi i tchnął w jego oblicze tchnienie życia".

${ }^{4}$ Chodzi tutaj o następujące komentarze: Augustinus, De Genesi ad litteram imperfectus liber, PL 34, 219-245, thum. J. Sulowski: Św. Augustyn, Niedokończony komentarz stowny do Księgi Rodzaju, w: Św. Augustyn, Pisma egzegetyczne przeciw manichejczykom, PSP 25, Warszawa 1980, 83-112; tenże, De Genesi ad litteram libri duodecim, PL 34, 245-485, thum. J. Sulowski: Św. Augustyn, Komentarz słowny do Księgi Rodzaju, PSP 25, 113-382; tenże, De Genesi contra Manichaeos, PL 34, 174-220, tłum. J. Sulowski: Św. Augustyn, Przeciwko manichejczykom komentarz do Księgi Rodzaju, PSP 25, 21-82.

${ }^{5}$ Augustinus, De Genesi contra Manichaeos II 7, 8, PL 34, 200, PSP 25, 57.
} 
„Owi przeciwnicy ksiąg Starego Testamentu, na wszystko patrząc cieleśnie i dlatego zawsze błądzący, również zwykli przyganiać kąśliwie i temu, że Bóg z mułu ulepił człowieka (de limo Deus hominem finxit). Powiadają zaś: «Dlaczego z mułu ulepił Bóg człowieka? Czyż nie miał lepszej materii niebieskiej, z której mógłby uczynić człowieka, że z błota ziemskiego ulepił tak słabego i śmiertelnego?»"6.

Św. Augustyn nie poprzestaje jednak na krytyce takiego zachowania, ale próbuje im odpowiedzieć racjonalnie i w oparciu o Pismo Święte. Zwracając się bezpośrednio do manichejczyków, biskup zarzuca im zwłaszcza niewiedzę, która stanowi podstawową przyczynę błędnego myślenia i niewłaściwego spojrzenia na człowieka:

„Przede wszystkim nie rozumieją, ile znaczenia w Piśmie Świętym posiada ziemia czy woda: a muł to pomieszanie wody z ziemią (limus enim aquae et terrae commixtio est)" ${ }^{\text {" }}$.

W dalszym wywodzie św. Augustyn stwierdza, że przyczyną słabości i śmiertelności ciała nie jest materia, z której ukształtowane zostało ciało człowieka, lecz grzech, który spowodował jego naturalne psucie i zniszczenie:

„Twierdzimy bowiem, że ciało ludzkie zaczęło być psującym się, słabym i skazanym na śmierć po grzechu (morti destinatum corpus humanum post peccatum esse coepisse). Sami w ludzkim ciele niczym innym się nie brzydzą jak tylko śmiertelnością, na którą zasłużyliśmy przez potępienie"».

Biskup Hippony zaznacza też, że gdyby człowiek był posłuszny Bogu, wówczas jego ciało nie tylko nie uległoby zepsuciu, ale też wolne by było od cierpień:

„Cóż więc dziwnego, albo trudnego dla Boga? Chociaż z mułu tej, tj. ziemi ulepił człowieka, to jednak stworzył mu takie ciało, które nie podlegałoby zniszczeniu (corpus eius efficere, quod corruptioni non subiaceret), gdyby człowiek zachowując przykazanie Boże nie dopuścił się grzechu (si homo praeceptum Dei custodiens peccare noluisset). Bo jeśli postać samego nieba uznajemy za stworzoną z niczego albo też z bezkształtnej materii, ponieważ wierzymy we wszechmocnego Stwórcę, to cóż dziwnego, że ciało, które powstało z jakiegokolwiek mułu, dzięki wszechmocy Stwórcy mogło być takim, iż nie ulegałoby żadnemu zniszczeniu (nulla corruptione), nie odczuwałoby żadnej dolegliwości (nulla molestia), ani żaden brak (nulla indigentia) nie dokuczałby człowiekowi przed grzechem?"9.

\footnotetext{
${ }^{6}$ Tamże.

7 Tamże.

${ }^{8}$ Tamże.

${ }^{9}$ Tamże.
} 
$\mathrm{Z}$ analizowanego powyżej fragmentu wypowiedzi św. Augustyna na temat Rdz 2, 7 wynika, że przyszły los ludzkiego ciała, czyli poddanie śmierci i jego rozpad nie zależał od materiału, w tym przypadku od mułu ziemi, z którego stworzony został człowiek. Przyczyna takiego stanu rzeczy zawsze jest jedna i leży w grzechu, który powoduje zniszczenie ciała.

O ukształtowaniu człowieka w dziele stworzenia mówi też św. Grzegorz z Nyssy w traktacie $O$ pochodzeniu człowieka ${ }^{10}$. Wyraźnie rozróżnia on stworzenie od ukształtowania. Według niego ciało człowieka zostało ukształtowane, podobnie jak kształtuje się model z gliny. Tym zaś, co zostało stworzone w człowieku jest dusza ${ }^{11}$. Prawdopodobnie $z$ tego też powodu biskup Nyssy dostrzega z jednej strony kruchość, z drugiej natomiast wielkość i wspaniałość człowieczeństwa. Powołując się bowiem na tekst Rdz 2, 7 św. Grzegorz stwierdza:

„«Bóg wziął proch ziemi i ukształtował człowieka» (Rdz 2, 7). W tych słowach

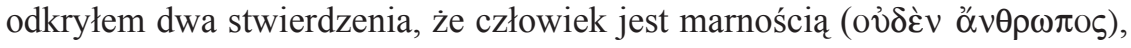
i że człowiek jest wielki ( $\mu \varepsilon \dot{\gamma} \alpha \alpha$ őv $\theta \rho \omega \pi$ s). Jeśli rozważysz samą naturę, jest on nikim i nie posiada żadnej wartości, lecz jeśli spojrzysz na godność z jaką został potraktowany, człowiek jest kimś wielkim"'12.

Samo zatem ciało, bez duszy niewiele znaczy, ponieważ ulega rozkładowi, ukształtowane bowiem zostało z prochu ziemi. Dopiero w połączniu z duszą nabiera właściwej sobie godności.

Św. Grzegorz z Nyssy zwraca też uwagę na sposób stworzenia człowieka, który różny jest od tworzenia zwierząt i całej otaczającej nas przyrody. W cytowanym już wcześniej dziele $O$ pochodzeniu człowieka pisze:

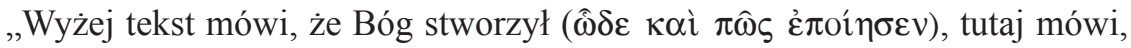

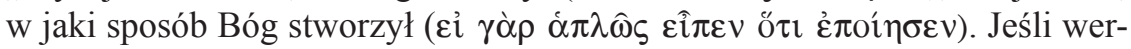
set mówiłby po prostu, że Bóg stworzył, mógłbyś uwierzyć, że tworzył, jak uczynił to w odniesieniu do bydła, dzikich zwierząt, roślin, trawy. Dlatego, aby uniknąc przekonania, że zaliczasz się do grona dzikich zwierząt, słowo Boże przedstawiło szczególną zdolność, jaką Bóg przejawia wobec ciebie. «Bóg wziął proch ziemi» $(\operatorname{Rdz} 2,7)$ "’3.

${ }^{10}$ Wymienione tutaj dzieło $O$ pochodzeniu człowieka występuje w postaci dwóch homilii i przypisywane było Bazylemu Wielkiemu (De hominis structura oratio I et II, PG 30, 9-61). W PG 44, 257-297 pojawia się jako dzieło Grzegorza z Nyssy i ma stanowić uzupełnienie homilii Bazylego O sześciu dniach stworzenia. W najnowszym natomiast wydaniu krytycznym opublikowanym w serii Sources Chrétiennes 160 (Paris 1970) pojawia się jako homilie Bazylego Wielkiego. Wydaje się, że ani jeden, ani drugi nie jest ich autorem. Należało jednak przyjąć jakiś punkt odniesienia i dlatego idąc za wskazaniem CPG (3215-3216) przypisujemy wspomniane homilie Grzegorzowi z Nyssy, a korzystamy z tekstu greckiego wydanego w SCh 160, pod imieniem Bazylego Wielkiego.

${ }^{11}$ Por. Gregorius Nyssenus, De creatione hominis sermo alter 2, 3, ed. A Smets - M. Van Esbroeck, SCh 160, Paris 1970, 232, thum. własne.

12 Tamże 2, 2, SCh 160, 228, thum. własne.

${ }^{13}$ Tamże 2, 4, SCh 160, 232, tłum. własne. 
To, co odróżnia zatem stworzenie człowieka od reszty stworzeń, mieści się w materii. Ani zwierzęta, ani też żadna roślinność nie zostały stworzone z prochu ziemi tak jak człowiek. Pewnym uzupełnieniem i kontynuacją powyższej myśli św. Grzegorza z Nyssy, może być wypowiedź Teodoreta z Cyru, który zwraca uwagę na ogromne zaangażowanie się Boga w ukształtowanie człowieka. W Zarysie historii herezji interpretuje Rdz 2, 7 w następujący sposób:

„Kiedy słyszymy opisy Mojżesza mówiące, jak Bóg wziął proch ziemi w swoje ręce, aby uczynić człowieka, staramy się zrozumieć, co takiego to może oznaczać. Oznacza to, że cały Bóg ${ }^{14}$ miał szczególny udział w two-

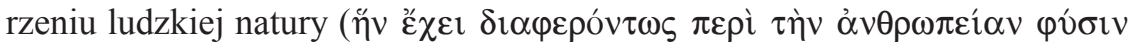

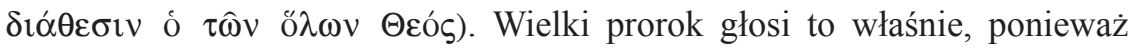
wszystko pozostałe tworzone było przez wypowiedziane polecenie. Człowiek

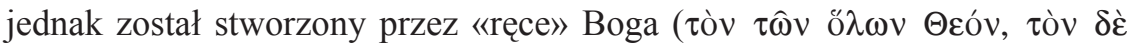

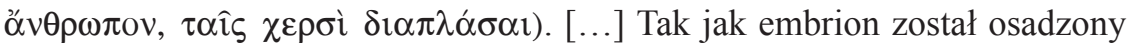
w łonie matki i rozwija się z materiału, który od początku go otacza, tak samo Bóg chciał wziąć do ludzkiego ciała materiał z ziemi. W ten sposób z gliny powstało ciało i krew, i skóra, i nerwy, żyły, tętnice, i mózg, szpik kostny i podpora kości, i tak dalej"15.

Kiedy Teodoret wymienia ,ręce Boga”, które brały udział w stworzeniu człowieka pragnie podkreślić, podobnie jak wcześniej widzieliśmy u św. Grzegorza z Nyssy, różnicę w stworzeniu świata zwierząt i roślin od ukształtowania człowieka. W pierwszym przypadku Bóg działał poprzez nakaz, chociażby taki, jak: ,Niech się stanie światłość” (por. Rdz 1, 3); „Niechaj powstanie sklepienie w środku wód i niechaj ono oddzieli jedne wody od drugich" (Rdz 1, 6); „Niechaj ziemia wyda istoty żywe różnego rodzaju” (Rdz 1, 24). W odniesieniu natomiast do człowieka mamy do czynienia z całkowicie innym określeniem. Nie jest to nakaz, ale pragnienie Boga, by dokonać aktu stworzenia człowieka, o czym jest mowa zarówno w pierwszym, jak i w drugim opisie stworzenia: „A wreszcie rzekł Bóg: «Uczyńmy człowieka na Nasz obraz, podobnego Nam»” (Rdz 1, 26); ,wtedy to Pan Bóg ulepił człowieka z prochu ziemi i tchnął w jego nozdrza tchnienie życia” (Rdz 2, 7). Dlatego też chyba Teodoret, ale również i wcześniejsi Ojcowie Kościoła używają obrazowego określenia, że Bóg posługiwał się rękami, by ukształtować człowieka. Chodzi tutaj o zwrócenie uwagi na wspomniane już wcześniej zaangażowanie się Boga w to dzieło i podkreślenie wyjątkowej roli i godności człowieka w całym wszechświecie, skoro uczyniony został inaczej niż pozostałe stworzenia.

W tym kontekście warto odnieść się do wcześniejszego jeszcze autora, do św. Ireneusza z Lyonu, który w dziele Wykład nauki apostolskiej pisze, iż Bóg:

14 W wyrażeniu „cały Bóg” Teodoret odnosi się do herezji Audiusza, diakona i mnicha syryjskiego żyjącego w Edessie w IV w. Założył on sektę audian głoszącą doktrynę o charakterze gnostyckim. Epifaniusz zarzucał mu antropomorfizowanie Boga, por. SWPW 235-236.

${ }^{15}$ Theodoretus Cyrensis, Compendium haereticarum fabularum V 9, PG 83, 477-480, tłum. własne. 
„Człowieka ukształtował własnymi rękami biorąc z ziemi to, co najczystsze i najdelikatniejsze i mieszając według odpowiedniej miary swoją moc z ziemi"16.

W Adversus haereses w kilku miejscach św. Ireneusz rozwija jeszcze szerzej ten wątek. Mówiąc bowiem o „rękach Boga” myślał o Synu i o Duchu' ${ }^{17}$. Stojąc w opozycji do gnostyków ${ }^{18}$, którzy utrzymywali, że w stworzeniu człowieka brali udział aniołowie, stwierdza, że

„Bóg nie potrzebował [...] ich pomocy dla stworzenia tego, co sam zamierzył stworzyć, jakby nie miał swoich własnych rąk. Jest przy nim stale i Słowo, i Mądrość, Syn i Duch, dzięki którym i przez których stworzył wszystko w sposób wolny i swobodny" 19 .

Nie tylko zatem Bóg Ojciec jest Stwórcą, lecz także o Synu i Duchu Świętym można powiedzieć, że czynnie uczestniczyli w tym dziele ${ }^{20}$. W przywołanych tekstach, w których pisarze wczesnochrześcijańscy komentują pierwszą część Rdz 2, 7, nacisk został położony na materialny element człowieka ukształtowany w akcie stworzenia. Ani jeden z zacytowanych autorów w żaden sposób nie umniejsza znaczenia ludzkiego ciała, przeciwnie, każdy wskazuje na jego godność i znaczenie. Podkreślona też została wyjątkowość człowieka pośród innych stworzeń, chociażby z tego powodu, że ukształtował go sam Bóg. Docenienie materii, w tym ludzkiego ciała, było konieczne nie tylko z uwagi na prawidłowo prowadzoną egzegezę biblijną, lecz także ze względu na toczone polemiki z gnostykami, manichejczykami, bądź z innymi grupami niedoceniającymi ludzkiego ciała ${ }^{21}$.

${ }^{16}$ Irenaeus Lugdunensis, Demonstratio praedicationis apostolicae 11, ed. L.-M. Froidevaux, SCh 62, Paris 1959, 48-49, thum. W. Myszor: Św. Ireneusz z Lyonu, Wykład nauki apostolskiej, ŹMT 7, Kraków 1997, 33.

${ }^{17}$ Termin „ręce Boga” był dosyć popularny w egzegezie patrystycznej. Pojawia się bowiem u wielu autorów wczesnochrześcijańskich. Więcej na ten temat por. B. Czyżewski, Le mystère de la Pâque selon „Peri Pascha” de Méliton de Sardes, w: „,Veritatem desiderat anima”. Studia patrystyczne z okazji 110 rocznicy urodzin Bertholda Altanera (1885-1964), red. N. Widok, Opolska Biblioteka Teologiczna 6, Opole 1995, 88-89.

${ }^{18}$ Więcej o polemice św. Ireneusza z gnostykami na temat udziału aniołów w stworzeniu świata, por. A. Orbe, La uncion del Verbo, Roma 1961, 58-75; por. także H. Pietras, Poczqtki teologii Kościoła, Kraków 2000, 246-247.

${ }^{19}$ Irenaeus Lugdunensis, Adversus haereses IV 20, 1, ed. A. Rousseau - B. Hemmerdinger C. Mercier - L. Doutreleau, SCh 100/2, Paris 1965, 629, thum. W. Myszor, w: Św. Ireneusz z Lyonu, Bóg $w$ Ciele i Krwi, BOK 16, Kraków 2001, 43. Ireneusz wyjaśnia w jeszcze innym miejscu, co rozumie przez „ręce Boga”: „Przez ręce Ojca, tj. przez Syna i Ducha powstaje człowiek na podobieństwo Boże, a nie tylko część człowieka” (tamże V 6, 1, ed. A. Rousseau - L. Doutreleau C. Mercier, SCh 153, Paris 1969, 74, thum. A Bober, w: AP 53.

20 Por. C. Bartnik, Dogmatyka katolicka, t. 1, Lublin 1999, 280-295; K. Góźdź, Sens chrześcijańskiej nauki o stworzeniu, „Scripturae lumen” 6 (2014) 355.

${ }^{21}$ Polecam obszerną monografię M. Szrama, który dokładnie opisuje antropologię autorów 
2. Dusza ludzka w dziele stworzenia. Pisarze wczesnochrześcijańscy komentując werset Rdz 2, 7 nie zatrzymywali się wyłącznie na materii, czyli na ciele, jakie człowiek otrzymał w dziele stworzenia. Zwracali uwagę także na jego duszę, o czym mówi druga część analizowanego tekstu: Bóg tchnął w nozdrza człowieka tchnienie życia (por. Rdz 2, 7). Zobaczymy na przykładzie kilku tekstów, w jaki sposób autorzy okresu patrystycznego wyjaśniali ten biblijny fragment.

Rozpoczniemy od krótkiego stwierdzenia Tertuliana, który w dziele $O d u$ szy pisze:

,już w polemice z Hermogenesem wykazaliśmy, że dusza wzięła początek $\mathrm{z}$ tchnienia Bożego, a nie z materii (animam ex Dei flatu, non ex materia uindicamus) - o czym wyraźnie świadczą słowa Objawienia: «I tchnął Bóg w twarz człowieka tchnienie żywota, i stał się człowiek duszą żywą» (Rdz 2, 7)"222.

Początek duszy ludzkiej upatruje zatem Tertulian w tym, co Księga Rodzaju nazwała tchnieniem Bożym. Wspomniany tutaj Hermogenes, gnostyk i kartagiński filozof uważał, że dusza człowieka wywodzi się z materii. Dlatego też Tertulian zdecydowanie się temu przeciwstawiał i jednoznacznie stwierdził, że posiada początek, źródłem zaś jej istnienia jest wspomniane w Biblii tchnienie Boga.

Warto odnieść się jeszcze do innego, chociaż późniejszego niż Tertulian, pisarza, mianowicie do św. Ambrożego z Mediolanu. Biskup zastanawia się nad naturą duszy. Najpierw, tak jak w teologii apofatycznej, św. Ambroży mówi czym dusza ludzka nie jest, by w końcu stwierdzić, czym jest. W dziele O Izaaku lub duszy, biskup Mediolanu pisze:

„dusza nie jest krwią, gdyż krew należy do ciała; dusza nie jest harmonią, ponieważ tego rodzaju harmonia należy do ciała. Nie jest też dusza tchnieniem powietrza, jako że czym innym jest wiejący wiatr, a czym innym dusza. Nie jest dusza ogniem, ani entelechią, lecz dusza jest istotą żyjącą (anima est uiuens). Dusza bowiem ożywia (anima uiuificet) i kieruje (gubernet) nieczułe i pozbawione życia ciało"23.

W powyższej wypowiedzi biskup Mediolanu powołuje się na opinie filozofów, m.in. perypatetyka Dicearcha z Messyny, stoików czy też Arystotelesa na temat duszy ${ }^{24}$. Dochodzi jednak do przekonania, że dusza ludzka daje ciału przede wszystkim życie. Nazywa ją nawet istotą żyjącą ze względu na jej dynamizm i żywotność.

wczesnochrześcijańskich, w tym także analizuje wiele tekstów patrystycznych odnoszących się do Rdz 2, 7: M. Szram, Ciało zmartwychwstałe w myśli patrystycznej przełomu II i III wieku, Lublin 2010.

${ }^{22}$ Tertullianus, De anima III 4, ed. J.H. Waszink, CCL 2, Turnhout 1954, 785-786, thum. własne.

${ }^{23}$ Ambrosius, De Isaac vel anima 2, 4, ed. C. Schenkl, CSEL 32/1, Vindobonae 1896, 644645, tłum. P. Libera: Św. Ambroży, O Izaaku lub o duszy, w: Św. Ambroży, Wybór pism, PSP 35, Warszawa 1986, 129.

${ }^{24}$ Por. tamże, nota 27. 
Temat ten rozwija św. Jan Chryzostom, co prawda, nie w polemice z filozofami, jak miało to miejsce w przypadku Tertuliana czy Ambrożego, ale wyjaśniając Księgę Rodzaju, w tym także interesujący nas werset Rdz 2, 7. Biskup Konstantynopola stwierdza:

„Mojżesz uczy nas, że człowiek, ukształtowany z mułu ziemi otrzymał, dzięki hojności Bożej, duszę istotowo rozumną i stał się w ten sposób bytem do-

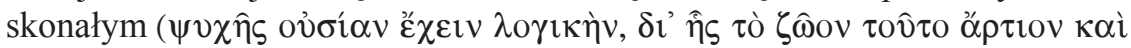
$\left.\tau \dot{\varepsilon} \lambda \varepsilon \iota_{0} \alpha_{\alpha} \pi \varepsilon \delta \varepsilon \dot{\kappa} \kappa v v \tau o\right)$. «A Bóg tchnął w nozdrza człowieka tchnienie życia» $(\mathrm{Rdz} 2,7)$. W ten sposób oznaczył duszę, która jest w człowieku uformowanym z mułu ziemi, początkiem życia, działania i ruchu"25.

Dostrzegamy wyraźną różnicę w tym, co nazwane zostało ciałem ukształtowanym przez Boga i duszą będącą owocem tchnienia Bożego. Dusza nie tylko ożywiła ciało Adama, ale będąc duszą rozumną sprawiła, że człowiek zaliczony został do bytów doskonałych. Jak wielka jest rola duszy w ciele wskazuje św. Jan Chryzostom w dalszej wypowiedzi na temat Rdz 2, 7. Zastanawia się mianowicie nad znaczeniem biblijnych słów, iż człowiek „stał się żyjący i ożywiony” (Rdz 2, 7). Według Chryzostoma terminy ,żyjący i ożywiony" mówią nie tylko o udzieleniu życia człowiekowi ulepionemu z mułu ziemi, ale oznaczają coś więcej. Od tego momentu człowiek „był panem swoich działan”, a „członki jego ciała były podporządkowane woli duszy”26.

Św. Bazyli Wielki z kolei w Homilii do Psalmu 29 mówi o umieszczeniu przez Boga części swojej łaski w duszy człowieka:

„«I tchnął w jego nozdrza» (Rdz 2, 7), to znaczy umieścił w człowieku jaką̧ś

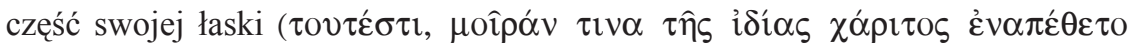

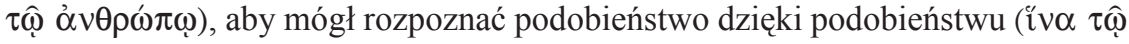

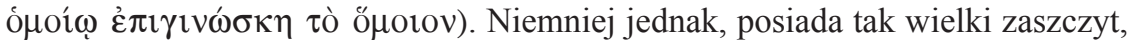
ponieważ został stworzony na obraz Stwórcy, zaszczycony został ponad niebiosa, nad słońce, nad chóry gwiazd. Do których ciał niebieskich mówiono, że jest obrazem Boga najwyższego? (por. Ps 8,$5 ; \mathrm{Hbr} 1,5)^{\prime 227}$.

Stwierdzenie powyższe nie oznacza, iż jakaś część natury Boga przeszła do duszy ludzkiej. Chodzi tutaj o łaskę podobieństwa człowieka do Boga. Problem ten wyjaśnia św. Augustyn w polemice z manichejczykami, którzy uważali, że dusza posiada naturę Boga. W jednym ze swoich komentarzy do Księgi Rodzaju biskup Hippony przekonuje swoich adwersarzy:

„Zdanie: «Tchnął w jego nozdrza tchnienie życia, wskutek czego stał się człowiek istotą żywą̧ (Rdz 2,7), nie każe nam wierzyć, jakoby jakaś część natury Boga przemieniła się w duszę człowieka. W ten sposób nie zmusza nas do przyznania, iż istota Boga jest zmienna. Manichejczyków trwających w tym

${ }^{25}$ Joannes Chrysostomus, In Genesim hom. 12, 15, PG 53, 103, thum. własne.

${ }^{26}$ Tamże.

${ }^{27}$ Basilius Caesariensis, Homiliae super Psalmos 29, 8, PG 29, 449, tłum. własne. 
właśnie błędzie najbardziej złości prawda. Ponieważ matką wszystkich herezji jest pycha, śmią twierdzić, że dusza posiada naturę Bożą. I tu przyciskamy ich do muru takim oto rozumowaniem. A więc natura Boga błądzi i jest nędzna i zepsuta skazą wad i grzeszy, a może nawet, co sami przyznajecie, zostaje skażona obrzydliwościami istoty przeciwnej! A te i tym podobne rzeczy nie godzi się przypisywać istocie Boga. Albowiem fakt, że duszę stworzył wszechmocny Bóg (factam esse animam ab omnipotente Deo), a zatem nie jest ona cząstką Boga (non illam esse partem Dei) ani nie ma natury Bożej (uel naturam Dei), podkreślony jest w innym miejscu, kiedy powiada prorok: «Ten, który tchnął we wszystko tchnienie, wszystko stworzył» (Ps 32, 15) a w innym miejscu: «I ducha tchnął we wnętrze człowieka» $(\mathrm{Za} \mathrm{12,1)}$ "28.

Biskup Hippony jednoznacznie opowiada się za tym, że Bóg jest stwórcą duszy ludzkiej i w żaden sposób nie stanowi ona cząstki substancji Bożej, o czym byli przekonani manichejczycy. Z drugiej jednak strony św. Augustyn nie odpowiada na pytanie o pochodzenie duszy ${ }^{29}$.

3. Jedność duszy i ciała w czlowieku. Przedstawiona do tego momentu interpretacja Rdz 2, 7 dokonana przez pisarzy wczesnochrześcijańskich pokazała, iż potwierdzają oni istnienie dwóch elementów konstytuujących człowieka. Są nimi: ciało ukształtowane z prochu czy też z mułu ziemi oraz rozumna dusza. Autorem jednego i drugiego jest Bóg Stwórca. Warto zapytać o jeszcze jedną kwestię, mianowicie dotyczącą wzajemnych relacji ciała i duszy oraz tego, który z tych dwóch elementów jest ważniejszy. Odpowiedź wydaje się być jednoznaczna, że dusza, skoro to ona ożywia ciało i nigdzie nie było mowy, iż jest zniszczalna, czego nie można powiedzieć o ciele człowieka. Takie stwierdzenie byłoby jednak zbyt dużym uproszczeniem, dlatego należy odnieść się do wypowiedzi Ojców i poszukać u nich odpowiedzi na wspomniane kwestie.

Okazuje się, że jednym z autorów wczesnochrześcijańskich, który zwraca uwagę na relację ciała i duszy w człowieku jest św. Grzegorz z Nyssy. W dziele $O$ stworzeniu człowieka wspomina o istniejącym poglądzie, wynikającym bardziej z logicznego rozumowania, jakoby istniał porządek stworzenia człowieka i on miałby decydować o większej wartości jednego elementu od drugiego. Biskup pisze o tym w taki sposób:

„Inni, uważając za słuszne trzymać się porządku stworzenia człowieka, o jakim mówi Mojżesz, mówią, że dusza jest w porządku czasowym później-

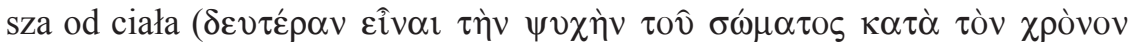
$\left.\varphi \alpha \sigma^{\prime} v\right)$, bo Bóg najpierw wziął proch z ziemi i utworzył człowieka, a potem,

\footnotetext{
${ }^{28}$ Augustinus, De Genesi contra Manichaeos II 8, 11, PL 34, 201-202, PSP 25, 58-59.

${ }^{29}$ Por. J. Słomka, Dzieło stworzenia w myśli patrystycznej, „Scripturae lumen” 6 (2014) 345.
} 
tchnąwszy w niego, obdarzył go duszą. Z tego, że [Bóg] umieścił duszę we wcześniej utworzonym ciele, ma wynikać, że ciało jest od niej cenniejsze"30.

Św. Grzegorz ustosunkowując się do tego poglądu stwierdza:

„nie podzielamy teorii, jakoby dusza została dana uprzednio utworzonemu ciału niby jakiemuś glinianemu posagowi, bo to by oznaczało, że natura rozumna jest mniej szacowna od gliny. Jako że człowiek złożony z duszy

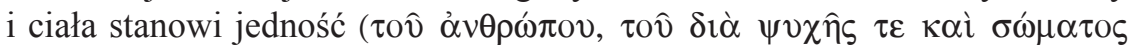
$\sigma v v \varepsilon \sigma \tau \eta \kappa o ́ \tau o \varsigma, ~ \mu i ́ \alpha v ~ \alpha \jmath ̉ \tau o v)$, należy założyć, że jeden i ten sam jest fundament i duszy, i ciała, bo gdyby element cielesny pojawił się wcześniej, a duchowy później, człowiek byłby starszy lub młodszy od siebie samego"31.

Wynika z tego, że św. Grzegorz z Nyssy uważa zarówno duszę, jak i ciało za jedność, oba też te elementy docenia i kładzie na tej samej płaszczyźnie znaczeniowej. Mówi biskup o tym samym fundamencie, przez co można z całą pewnością rozumieć Boga Stwórcę. On przecież - o czym była już wielokrotnie mowa - ukształtował człowieka i tchnął w niego życie w postaci duszy rozumnej. Grzegorz wyraźnie polemizuje tutaj ze zwolennikami preegzystencji dusz, zwłaszcza z Orygenesem i z teorią metempsychozy. Podobnie jak Platon i Arystoteles, biskup Nyssy jest zdania, że dusza ożywia materialne ciało. W Dialogu z siostrq Makrynq o duszy i zmartwychwstaniu wprost nazywa duszę ożywiającą i życiodajną przyczyną ${ }^{32}$. Św. Grzegorz jest też przekonany o zaistnieniu duszy i ciała w chwili poczęcia. Nie można zatem mówić o powstaniu ciała przed duszą i odwrotnie. $Z$ tego też powodu niektórzy badacze nauki biskupa Nyssy widzą w nim traducjanistę ${ }^{33}$, co w żaden sposób nie znajduje potwierdzenia $\mathrm{w}$ jego nauce. Nie jest on bowiem ani traducjanista, ani też kreacjonistą ${ }^{34}$.

Podobne poglądy na temat jedności duszy i ciała co św. Grzegorz z Nyssy wyraża też św. Jan Damasceński. Odcina się od teorii preegzystencji dusz, a tym samym od Orygenesa. Podobnie jak Grzegorz, Jan również uważa, iż dusza powstaje równocześnie z ciałem w chwili poczęcia. Mówi o tym w $W y$ kładzie wiary prawdziwej:

${ }^{30}$ Gregorius Nyssenus, De opificio hominis 28, PG 44, 229, tłum. M. Przyszychowska: Św. Grzegorz z Nyssy, O stworzeniu człowieka, ŹMT 39, Kraków 2006, 132-133.

${ }^{31}$ Tamże 28-29, PG 44, 233, ŹMT 39, 135-136.

${ }^{32}$ Por. tenże, Dialogus de anima et resurrectione, PG 46, 16-17, tłum. W. Kania: Św. Grzegorz z Nyssy, Dialog z siostra Makrynq o duszy i zmartwychwstaniu, w: Św. Grzegorz z Nyssy,

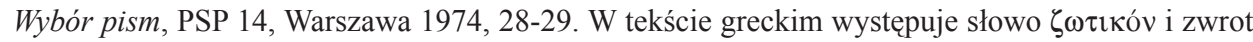

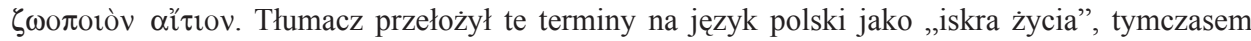

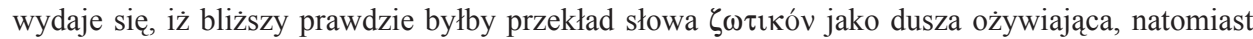

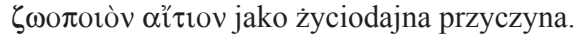

${ }^{33}$ Por. m.in. J.N.D. Kelly, Poczqtki doktryny chrześcijańskiej, tłum. J. Mrukówna, Warszawa $1988,257$.

${ }^{34}$ Por. M. Przyszychowska, Wstęp, w: ŹMT 39, 34-36. 
„Tworzy [Bóg] człowieka własnymi rękami z natury widzialnej i niewidzialnej na swój obraz i podobieństwo (por. Rdz 1, 26), przy czym ciało jego buduje z ziemi, a z własnego tchnienia wlewa weń duszę rozumną i myślącą, która przedstawia właśnie Boski obraz. [...] Równocześnie zatem po-

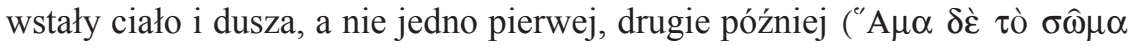

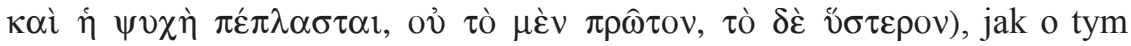
majaczył Orygenes" 35 .

Na jedność duszy i ciała w człowieku stworzonym przez Boga wskazuje też św. Jan Chryzostom. W swoich Homiliach na Księgę Rodzaju mówi:

„Bóg rozlał na obliczu człowieka tchnienie życia i człowiek stał się żyjący i ożywiony. Co oznaczają słowa: rozlał tchnienie życia? Uczą nas one, że Bóg jednoczy ciało człowieka z duszą żyjąca, która mu przekazuje życie

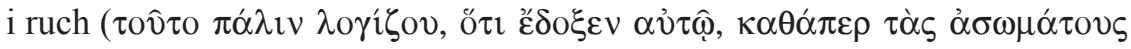
$\delta v v \alpha ́ \mu \varepsilon ı \varsigma \pi \alpha \rho \eta ́ \gamma \alpha \gamma \varepsilon v)$, i która posługuje się członkami tego samego ciała, aby ćwiczyć własne zdolności"36.

Biskup Konstantynopola zwraca uwagę na jedność duszy i ciała człowieka, o co zadbał sam Bóg w dziele stworzenia. Dusza pozostaje przyczyną wszelkich funkcji życiowych ciała.

Warto raz jeszcze powrócić do św. Augustyna, który wyjaśnia, czym było opisane w Księdze Rodzaju tchnienie Boga:

„Pismo powiada: «I tchnął w jego nozdrza tchnienie życia, wskutek czego stał się człowiek istotą żywą» ( $\mathrm{Rdz} 2,7)$. Jeśli było to jeszcze tylko ciało, to w tym miejscu trzeba przyjąć, że dusza została dołączona do ciała (animam adiunctam corpori), niezależnie od tego, czy była już stworzona, ale niejako w ustach Boga, czyli w Jego prawdzie i mądrości. Jednak nie wyszła jakoby opuszczając jakieś miejsce, kiedy została tchnięta. Bóg przecież nie zajmuje miejsca, lecz wszędzie jest obecny"37.

Według św. Augustyna Bóg zjednoczył duszę ludzką z ciałem przez swoje tchnienie. W innym zaś komentarzu w ciekawy sposób rozwinął tę myśl. Powiedział mianowicie, że Bóg, który ożywił pierwszego człowieka i uczynił go z mułu ziemi, dał jego ciału duszę. Jezus natomiast tchnął w nas i tym samym dał nam drugie tchnienie - Ducha Świętego i stworzył nową ludzkość, przez co:

„,zaznaczył, iż jest Tym, który tchnął w ich oblicze (insufflauit in faciem eorum), aby z mułu powstali i brudnych czynów się wyrzekli (luteis operibus renuntiarent)" ${ }^{\prime 38}$.

${ }^{35}$ Joannes Damascenus, Expositio fidei II 12, PG 94, 919-922, thum. B. Wojkowski: Św. Jan Damasceński, Wykład wiary prawdziwej, Warszawa 1969, 94.

${ }^{36}$ Joannes Chrysostomus, In Genesim hom. 13, 9, PG 53, 107, tłum. własne.

${ }^{37}$ Augustinus, De Genesi contra Manichaeos II 8, 10, PL 34, 201, PSP 25, 58.

${ }^{38}$ Tenże, In Johannis Evangelium tractatus 32, 6, 2, ed. R. Willems, CCL 36, Turnhout 1954, 
Biskup Hippony nawiązując do stworzenia pierwszego człowieka zaznacza, że tak jak w raju miało miejsce Boże tchnienie w ludzkie ciało, tak też jest w przypadku kolejnych pokoleń. Człowiek staje się nowym stworzeniem przez dar Ducha Świętego, poprzez Jego tchnienie otrzymuje łaskę, by podjąć walkę z grzechem i słabością.

Podsumowując egzegezę pisarzy wczesnochrześcijańskich odnoszącą się do Rdz 2, 7 należy stwierdzić, że zawiera ona trzy istotne elementy. Po pierwsze Ojcowie wskazują na materię, z której uczyniony został przez Boga człowiek. Manichejczycy przekonywali swoich wyznawców i oponentów, że jest ona czymś złym, czemu stanowczo przeciwstawiali się pisarze chrześcijańscy. Ojcowie Kościoła mówili bowiem, że chociaż ludzkie ciało ulega naturalnemu rozkładowi, to jednak nie z powodu materiału, z jakiego jest zbudowane, lecz przyczyną jego kruchości pozostanie zawsze grzech. Można też zauważyć u komentatorów Rdz 2, 7 ustawiczne podkreślanie wartości i godności ludzkiego ciała.

Po drugie Ojcowie zwracają uwagę na duszę, która swój początek bierze $z$ tego, co Księga Rodzaju nazywa tchnieniem Bożym. Nie istniała ona jednak przed stworzeniem materialnego ciała, jak głosił Orygenes, ale stworzona została wraz z ciałem. Dusza ożywia ciało, wprawia je w ruch. Chociaż człowiek został ukształtowany z prochu ziemi rękami Boga, powinien być jednak postrzegany jako istota duchowa. Dusza jest stworzona, ciało natomiast zostało ukształtowane i to wyraźnie różnicuje te dwa elementy. Wspomnianą wielkość i wspaniałość człowieka dostrzec można w duszy żyjącej w ludzkim ciele. Dlatego też ludzkości nie da się zredukować do życia zwierząt, ponieważ rozumna ludzka dusza ożywia ciało.

Trzeci wreszcie wątek, jaki pojawia się w związku z egzegezą Rdz 2, 7 to wskazanie na zjednoczenie ciała i duszy w chwili stworzenia. Nastapiło ono w momencie, kiedy Bóg tchnął w nozdrza człowieka i umieścił w nim jakąś część swojej łaski. Nie oznacza to jednak, że natura Boga zmieniła się w duszę człowieka. Nie tylko pierwszy człowiek otrzymał tchnienie Boże. Każdy człowiek uzyskuje bowiem drugie tchnienie - Ducha Świętego, co prowadzi do stworzenia nowej ludzkości. 


\section{PATRISTIC INTERPRETATION OF GEN 2:7: \\ “AND THE LORD GOD FORMED MAN OF THE DUST OF THE GROUND, AND BREATHED INTO HIS NOSTRILS THE BREATH OF LIFE"}

\section{(Summary)}

The article aims at the presentation of the exegesis of Gen 2:7 made by some early Christian writers. Their interpretation contains three essential elements. Fathers start with pointing out the matter as a material from which God created man. Although the human body undergoes natural decomposition, it is not because of the material from which it is built, but because of its frailty due to sin. Fathers also pay attention to the soul, which has its source in what Genesis calls the breath of God. However, it did not exist before the creation of the material body, as proclaimed by Origen, but was created along with the body. The soul animates the body putting it in motion. Although man was formed from the dust of the earth by the hands of God, he should be seen as a spiritual being. Whereas the soul is created, the body has been formed and this clearly differentiates the two. Due to the greatness and grandeur of man, he cannot be reduced to animal being, as it has a rational soul that animates his body. Finally, the third thread in connection with the exegesis of the Gen 2:7 indicates the union of the body and the soul at the moment of creation. It occurred at the time when God breathed into man's nostrils and put in some part of his grace. This does not mean, however, that the nature of God has changed into the soul of man. Not only did the first man receive the breath of God - everyone gets a second breath, the Holy Spirit, which leads to the creation of a new humanity.

Key words: soul, body, Genesis, Creator, creation, man, Fathers of the Church.

Słowa kluczowe: dusza, ciało, Księga Rodzaju, Stwórca, stworzenie, człowiek, Ojcowie Kościoła.

\section{BIBLIOGRAFIA}

\section{Źródła}

Ambrosius, De Isaac vel anima, ed. C. Schenk1, CSEL 32/1, Vindobonae 1896, 641-700, tłum. P. Libera: Św. Ambroży, O Izaaku lub o duszy, w: Św. Ambroży, Wybór pism, PSP 35, Warszawa 1986, 126-172.

Augustinus, De Genesi ad litteram imperfectus liber, PL 34, 219-245, thum. J. Sulowski: Św. Augustyn, Niedokończony komentarz słowny do Księgi Rodzaju, w: Św. Augustyn, Pisma egzegetyczne przeciw manichejczykom, PSP 25, Warszawa 1980, 83-112.

Augustinus, De Genesi ad litteram libri duodecim, PL 34, 245-485, tłum. J. Sulowski: Św. Augustyn, Komentarz słowny do Księgi Rodzaju, w: Św. Augustyn, Pisma egzegetyczne przeciw manichejczykom, PSP 25, Warszawa 1980, 113-382.

Augustinus, De Genesi contra Manichaeos, PL 34, 174-220, tłum. J. Sulowski: Św. Augustyn, Przeciwko manichejczykom komentarz do Księgi Rodzaju, w: Św. Augustyn, Pisma egzegetyczne przeciw manichejczykom, PSP 25, Warszawa 1980, 21-82. 
Augustinus, In Johannis Evangelium tractatus, ed. R. Willems, CCL 36, Turnhout 1954, tłum. W. Szołdrski: Św. Augustyn, Homilie na Ewangelię św. Jana, w: Św. Augustyn, Homilie na Ewangelię i 1 List św. Jana, PSP 15, Warszawa 1977, z. 1, s. 27-551, z. 2, s. 9-379.

Basilius Caesariensis, Homiliae super Psalmos, PG 29, 209-494.

Gregorius Nyssenus, De creatione hominis sermo alter, ed. A Smets - M. Van Esbroeck, SCh 160, Paris 1970, 166-220.

Gregorius Nyssenus, De opificio hominis, PG 44, 123-256, tłum. M. Przyszychowska: Św. Grzegorz z Nyssy, O stworzeniu człowieka, ŹMT 39, Kraków 2006.

Gregorius Nyssenus, Dialogus de anima et resurrectione, PG 46, 11-160, thum. W. Kania: Św. Grzegorz z Nyssy, Dialog z siostra Makrynq o duszy i zmartwychwstaniu, w: Św. Grzegorz z Nyssy, Wybór pism, PSP 14, Warszawa 1974, 27-87.

Irenaeus Lugdunensis, Adversus haereses IV-V, IV: ed. A. Rousseau - B. Hemmerdinger - C. Mercier - L. Doutreleau, SCh 100/2, Paris 1965; V: ed. A. Rousseau - L. Doutreleau-C. Mercier, SCh 153, Paris 1969.

Irenaeus Lugdunensis, Demonstratio praedicationis apostolicae, ed. L.-M. Froidevaux, SCh 62, Paris 1959, thum. W. Myszor: Św. Ireneusz z Lyonu, Wykład nauki apostolskiej, ŹMT 7, Kraków 1997.

Joannes Chrysostomus, In Genesim hom., PG 53, 21 - 54, 580.

Joannes Damascenus, Expositio fidei, PG 94, 789-1228, thum. B. Wojkowski: Św. Jan Damasceński, Wykład wiary prawdziwej, Warszawa 1969.

Tertullianus, De anima, ed. J.H. Waszink, CCL 2, Turnhout 1954, 779-869.

Theodoretus Cyrensis, Compendium haereticarum fabularum, PG 83, 336-556.

\section{Opracowania}

BARTNIK C., Dogmatyka katolicka, t. 1, Lublin 1999.

Costacurta B., Obietnica życia w Księdze Rodzaju, tłum. D. Piekarz, Kraków 2004.

Czyżewski B,, Le mystère de la Pâque selon „,Peri Pascha” de Méliton de Sardes, w: ,, Veritatem desiderat anima”. Studia patrystyczne z okazji 110 rocznicy urodzin Bertholda Altanera (1885-1964), red. N. Widok, Opolska Biblioteka Teologiczna 6, Opole 1995, 53-116.

CzyżEwski B., ,, Uczyńmy człowieka na Nasz obraz, podobnego Nam” (Rdz 1,26) w interpretacji Ojców Kościoła, SG 25 (2011) 113-126.

GóźDź K., Sens chrześcijańskiej nauki o stworzeniu, „Scripturae lumen” 6 (2014) 349-361.

Kelly J.N.D., Poczqtki doktryny chrześcijańskiej, tłum. J. Mrukówna, Warszawa 1988.

Orbe A., La uncion del Verbo, Roma 1961.

Pietras H., Poczatki teologii Kościoła, Kraków 2000.

Przyszychowska M., Wstęp, w: Św. Grzegorz z Nyssy, O stworzeniu człowieka, ŹMT 39, Kraków 2006, 5-38.

SŁomka J., Dzieło stworzenia w myśli patrystycznej, „Scripturae lumen” 6 (2014) 335-347.

Starowieyski M., Słownik wczesnochrześcijańskiego piśmiennictwa Wschodu, Warszawa 1999.

Szram M., Ciało zmartwychwstałe w myśli patrystycznej przełomu II i III wieku, Lublin 2010. 